\title{
RESEARCH ON THE BIOLOGY OF TERRESTRIAL ISOPODS: A HISTORICAL SURVEY
}

\author{
Helmut Schmalfuss \\ Staatliches Museum für Naturkunde, Rosenstein 1, 70191 Stuttgart, Germany \\ E-mail: helmut.schmalfuss@gmx.de
}

\begin{abstract}
Even if we have written testimony that the ancient Greek intellectuals were already aware of the existence of woodlice, the history of scientific research on this group of animals starts 2000 years later. Beginning with Linnaeus, this survey portrays the more important researchers in this field, trying to outline the development from descriptive taxonomy into a broad field of biological science. Today isopodological research includes studies on ecology, behavior, nutritional biology, anatomy, functional morphology, neurology, physiology, biogeography, systematics, and phylogenetic analyses based on morphological and molecular data.
\end{abstract}

Keywords: terrestrial isopods, biology, history

\section{ANCIENT AUTHORS}

When I started to prepare this paper, there was the question: How to begin? And as every presentation on natural history begins with Aristoteles I decided to start with this ancient universal genius. I had however never heard that such humble creatures as isopods had attracted his attention. To be sure I asked his recent countryman Spyros Sfenthourakis, and of course, he knew it better and immediately sent me this citation from one of the natural history

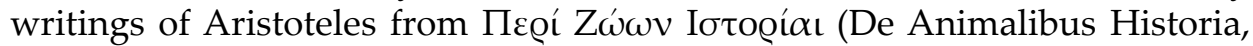
Book $\mathrm{V}$, chapter 25):

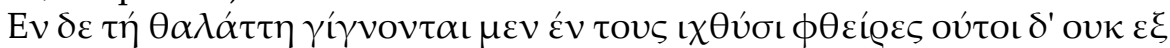

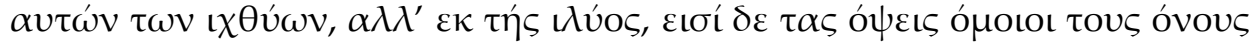

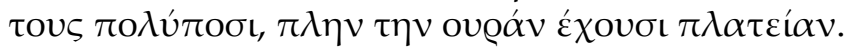

(In the sea there are lice on the fishes that do not originate from the fishes themselves but from the mud, and they look alike the many-legged donkeys, only that these have a flat tail.)

So this was probably the first time that mankind showed, in a written document which has been saved until today, that they recognized isopods as a separate group of animals - even if there is a high probability that already Paleolithic people did so (Fig. 1).

Please note this Greek word 'óvos'; we will return to this point later on.

It may be possible that in Roman times there were some natural history writings in which isopods may have been mentioned - one suspicion is Plinius 
(Plyni the Elder), who might also have copied some parts of the books of Aristoteles, but I did not check this, neither the natural history books of the Middle Ages, because if they mentioned our animals at all there was no real progress in the knowledge on the isopod biology.

\section{Carl Linnaeus}

This progress began in the 18th century and was triggered by a change in the background of European culture which we call the renaissance in combination with new technical achievements like the invention of the microscope.

So we jump now 2000 years and continue with what might be called the beginning of modern biological research.

It was the Swedish scientist Carl Linnaeus, who published in 1735 a book with the title Systema Naturae. In this book he realized the idea of naming plant species with a genus name and a species name, using Latin or Greek words. Under the genus name he united a number of similar species - the idea that organisms had phylogenetic relationships was yet completely unknown.

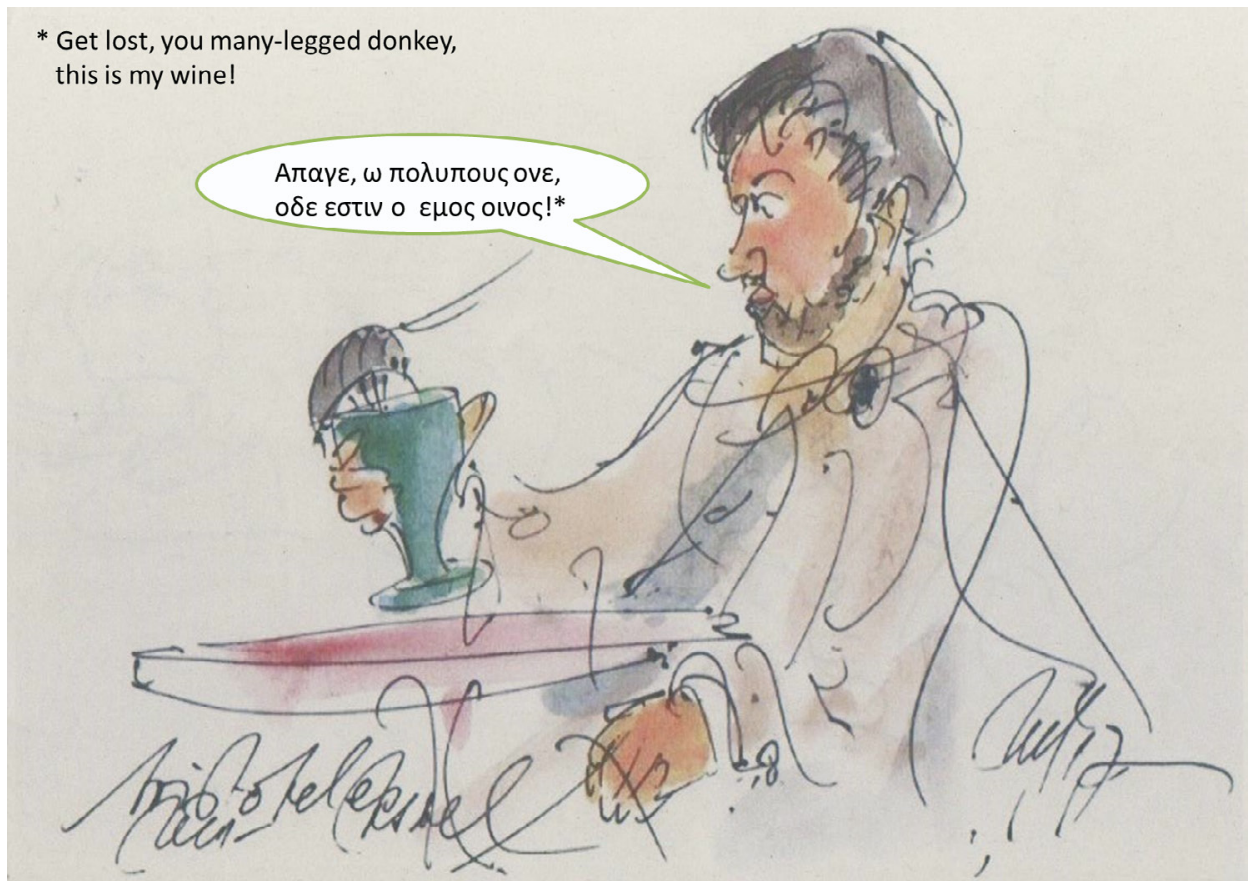

Fig. 1. Aristoteles was the first human being who mentioned woodlice in a written document saved until today. The cartoon visualizes one possible situation how he became aware of these animals (artist: Ulf Harr) 
In the 10th edition of this book, in 1758, he named and described more than 12000 animal and plant species.

This 10th edition contained an animal species which Linnaeus had named Oniscus asellus. It was the first species of terrestrial isopods described in modern systematics. Oniscus is the Latinized diminutive of the Greek word "onos" which means donkey. Aristoteles had called the woodlice the multilegged donkeys, and as we can suppose that Linnaeus knew the writings of the ancient authors, it is obvious that we owe to Aristoteles the name Oniscus and the family name Oniscidae derived from Oniscus and even the name of the whole suborder Oniscidea.

Linnaeus united under the name Oniscus a number of different isopod species, even from marine groups. So for him, the genus name Oniscus was used for different members of what we call today the order Isopoda.

\section{TH CENTURY}

During the next 100 years, this group was split up in more and more different genera and families and even different suborders of the order Isopoda by authors like Fabricius, Latreille, Brandt, Dana, Kinahan and a number of other authors. This was done in publications often dedicated to a wide variety of arthropods. The descriptions given by these authors of the 19th century are today insufficient to recognize the species, at least if they did not contain any illustrations. Some authors supplemented the descriptions by drawings, which were sometimes amazingly exact and are even today still useful depictions of diagnostic characters (Fig. 2).

\section{Joseph Schöbl}

The bulk of the 19th century literature on isopods consists of taxonomic publications, in which the descriptions of new species comprise some lines on superficial characters. There is one exception, which is a monographic, very extensive description of a species which was later synonymized with Platyarthrus hoffmannseggii Brandt, 1833, with 50 text-pages and 52 outstanding and exact illustrations. It was published in 1860 by Joseph Schöbl (Fig. 3) from Prague.

He also investigated the internal anatomy, as $\mathrm{f}$. i. the very complicated digestive system, and it is quite unbelievable which details he saw with a technical equipment of 1860 .

There were other authors in the 19th century who began to investigate skeletal morphology, internal anatomy, histology, and physiology of isopods. 
Путешестве въ Туркестанъ А.ПІ. Федченко

CRUSTACEA IV.
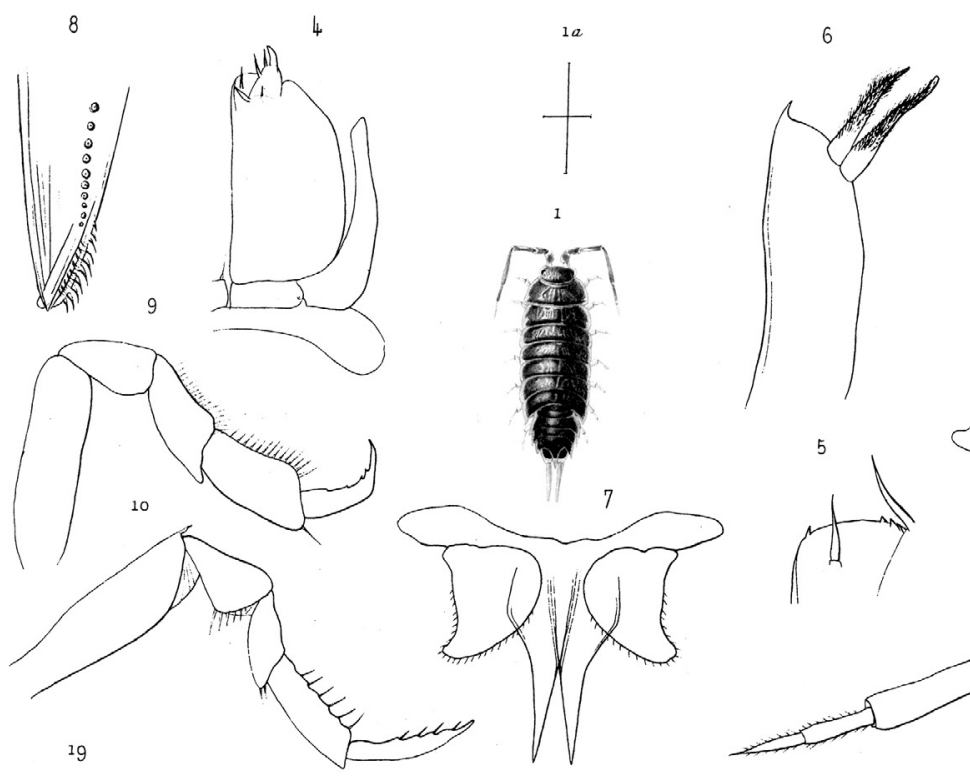

3
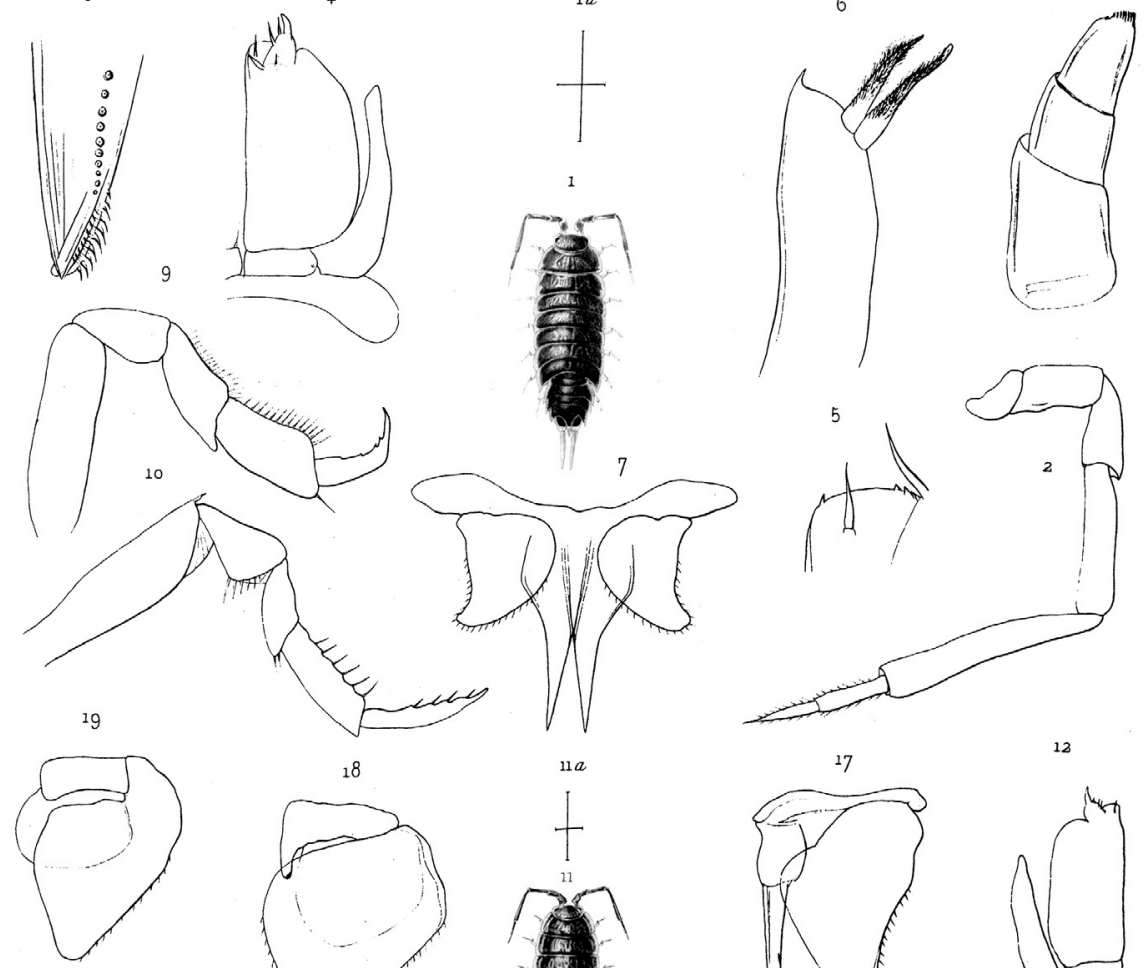

18

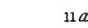

17

12

21
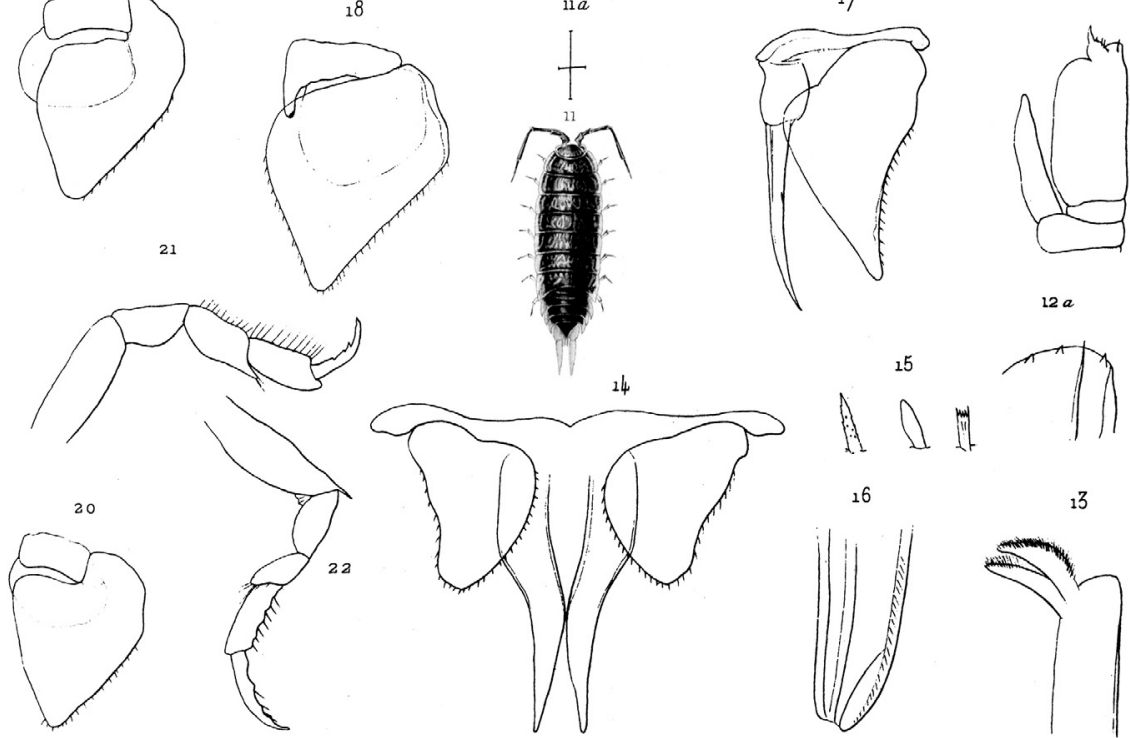

13

Paschkinn at nat. pins

Fig. 2. ULJANIN (1875) is one author from the 19th century, who supplemented his descriptions by drawings, which were amazingly exact and are even today still useful depictions of diagnostic characters 
I have compiled the following list of publications (certainly not complete) on the biology of terrestrial isopods beyond taxonomy and distribution, to show that already in that time there were scientists who investigated nearly all aspects of the life of woodlice. Publications from 19th century on non-taxonomic topics are as follows: Brandt (1871), Bobretzky (1874), Conklin (1897), Duvernoy \& Lereboullet (1841), Friedrich (1883), Huet (1883), Leydig (1878), Martynov (1896), McMurrich (1895), McMurrich (1898), Nusbaum (1893), Nusbaum (1896), Reinhard (1887), Roule (1891), Sсhöbl (1880), Schönichen (1899), Stoller (1899), Wagner (1865), Weber (1881).

\section{Gustav Budde-Lund}

In 1885 something happened which brought the systematics of terrestrial isopods on a new level. A book was published, comprising 320 pages, in which 170 new species of terrestrial isopods were described. It was written in Latin, and the author was Gustav Budde-Lund (Fig. 4) from Copenhagen. In addition, the book listed all terrestrial isopod species described in older publications, so this added up to 385 species known at that time. 120 years later this number had increased ten times (see Schmalfuss 2003), but nevertheless, Budde-Lund had achieved a tremendous task, for which he had borrowed

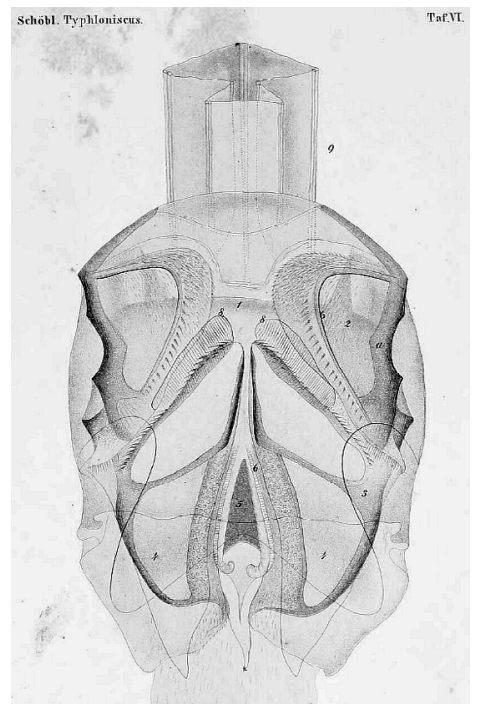

Fig. 3. In 1860 Schöbl illustrated the stomach of Platyarthrus hoffmannseggii (Typhloniscus steinii is a synonym) consider that the whole animal is only $3 \mathrm{~mm}$ long

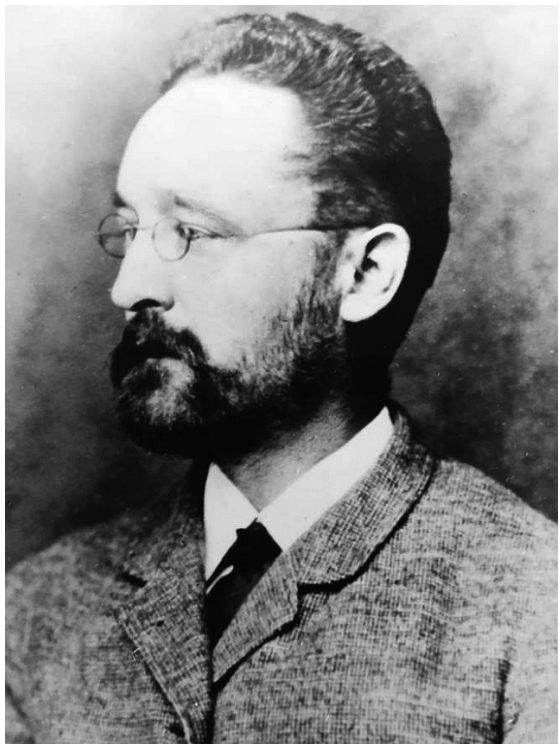

Fig. 4. The Danish isopod researcher Gustav Budde-Lund (1846-1911) (courtesy of Dr. Jørgen Olesen from the Natural History Museum of Copenhagen) 
isopod collections from many museums. His descriptions were very extensive and detailed, considering the knowledge of that time, and he also redescribed more than 100 species insufficiently described by former authors, which he found in the investigated collections. Seemingly a shortcoming of these descriptions was the lack of illustrations, but it would have been impossible to publish descriptions of 270 species with illustrations.

Although Budde-Lund never had a position as a zoologist, he went on in his spare time to study and publish on terrestrial isopods and was the leading specialist on this group of animals in his time. He published 23 partly very extensive papers on terrestrial isopods from all over the world. In the end, he had described 433 new species, and the publications after 1885 often contained many exact illustrations. JEPPESEN (2000) has listed all terrestrial isopod taxa described by Budde-Lund. This publication also contains a short biography of Budde-Lund. He died in 1911.

\section{TH CENTURY}

The first half of the 20th century was then dominated by four prominent isopodologists. The oldest was the German author Karl Verhoeff, followed by the Italian Alceste Arcangeli, the French Albert Vandel, and the Austrian Hans Strouhal.

\section{Karl Verhoeff}

Karl Verhoeff (1867-1944) (Fig. 5) was born in Soest in northern Germany. He studied at the University of Bonn and spent some years in Berlin. The last part of his life he spent in Munich, where he died in 1944, as a consequence of a bomb attack which destroyed his house.

Verhoeff was a very prolific scientist. Altogether he produced 670 publications, not only on isopods but also on a number of insect groups and centipedes and millipedes. He started publishing in the year 1890, and when his first paper on isopods appeared in 1896, he had already published more than 100 papers on different groups of other arthropods. In his 125 publications on terrestrial isopods, he treated mainly collections from Europe, but also material from South America, Indo-Australia, and Africa. This excessive overproduction had, of course, its negative side. The publications were often very chaotic and superficially arranged, without any critical control. One consequence of this was that Verhoeff, at least as far as isopods are concerned, described many species several times. The descriptions were insufficient to recognize the species, obviously also for the author, who 10 years later described the same species a second time. The situation became worse by the fact that Verhoeff, 
who most of the time did not have a position with a salary (except for the period from 1900 to 1905 at the Natural History Museum in Berlin), sold his type material to foreign museums because he needed the money to live on. So the material was out of his hands when he would have needed it for comparisons. For subsequent scientists working in this field this was a very tedious situation, if you wanted to become familiar with the species in a certain region, anyhow in Europe, in many cases you had to revise type-material to be sure about the identifications.

On the other hand, Verhoeff had a very wide biological interest and observed and published findings on ecology, physiology, reproduction, morphology, anatomy, phylogeny and biogeography, which were often not considered by the other, more taxonomically orientated specialists. Verhoeff also undertook a remarkable number of collecting expeditions to countries of southern Europe, contrary to his contemporary colleagues who restricted their collecting activities to their home countries.

In 1962 a self-portrayal written by Verho-

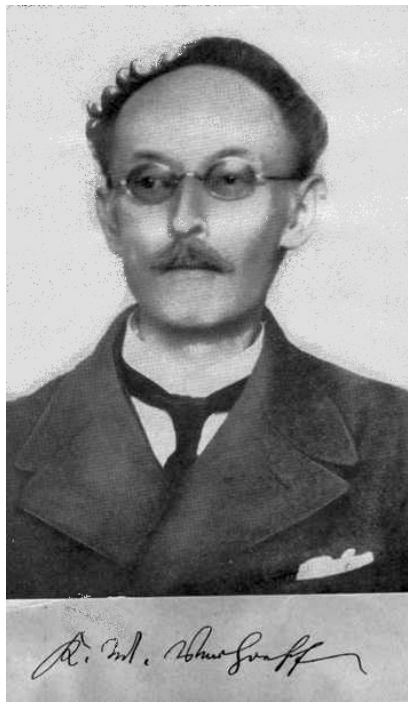

Fig. 5. The German author Karl Verhoeff (1846-1911) (from a self-portrait of VerHOEFF which was written in 1942 and published in 1962 in the series "Lebensdarstellungen deutscher Naturforscher") eff in 1942 was published in the series "Lebensdarstellungen deutscher Naturforscher", which was edited by the Deutsche Akademie der Naturforscher Leopoldina (50 pp., including a complete bibliography of Verhoeff's publications). An obituary was written by STRASSER (1949).

\section{Alceste Arcangeli}

Alceste Arcangeli (1880-1965) (Fig. 6) was born in Pisa and held positions at several Italian universities, until from 1930 to 1945 he became the Head of the Department of Zoology at the University of Torino in northern Italy.

Arcangeli published around 160 papers on terrestrial isopods and described 175 new species, counting only those that are considered valid today. His main interest was dedicated to the Italian fauna, but there were also publications on other Mediterranean countries and quite a number of articles on isopods from other continents. Besides this, Arcangeli revised single genera or families, reflecting on systematic relationships. Most of his publications are 


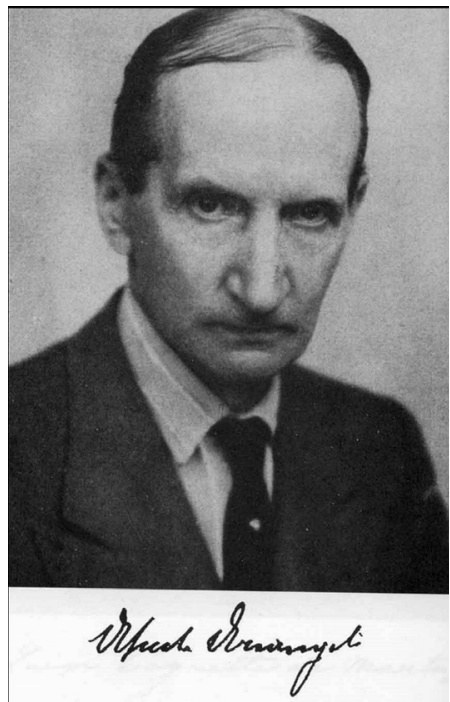

Fig. 6. The Italian author Alceste Arcangeli (1880-1965) (from an obituary published in 1967 by Guido Bacci in the Annuario della Universitá di Torino)

accompanied by high-quality illustrations. The main object of these publications was systematics and distribution, in a few articles sex determination, reproduction and pigmentation were treated.

In 1935 Arcangeli published an article with the title "Eoniscus simplicissimus, un pigmeo degli isopodi terrestri, appartenente a nuova specie, nuovo genere, nuova famiglia" (ArCANGeli 1935). This induced Verhoeff to a response in the form of a publication with the title: On a supposedly new isopod family. This article began with: "Errare humanum est, and also scientist are humans and can make mistakes. But for a scientist, there are two categories of errors: forgivable and unforgivable ones. And what Mr. Arcangeli has done is unforgivable." Because Arcangeli had investigated the larva of a diplopod, which by bad luck had just seven dorsal plates, and he mistook it for an isopod. Of course, Verhoeff, being also a specialist on millipedes recognized this immediately. Because Arcangeli was just as convinced of himself as Verhoeff, from that moment on the two, Arcangeli and Verhoeff, lived in a continuous feud and hostility. In many subsequent publications of either of them, there was a chapter on the mistakes and deficiencies of the other one. What we learn from this story is that persons with alleged high integrity like scientists can have all the strong points and all the shortcomings which characterize all human beings. (1967).

Arcangeli died in 1965, aged 84 . An obituary was written by GuIDo BACCI

\section{Albert Vandel}

Albert Vandel (1894-1980) (Fig. 7) was born in Besançon in central France. He spent his scientific career at the University of Toulouse in southern France, where he was Professor of Zoology from 1930 to 1965. In 1948 he founded, together with René Jeannel, a Subterranean Laboratory in Moulis in the French Pyrenees.

Vandel published his first paper on isopods in 1922 and produced another 200 publications on terrestrial isopods until 1981. He described more than 
330 new species, and he had a very systematic way of dealing with these species and/or a very good memory, so he rarely described the same species a second time. Of the prominent isopodologists of the first half of the 20th century he had certainly the most comprehensive knowledge of terrestrial isopods on a global scale. Again, his main interests were on systematics and biogeography, but he also investigated sex determination, reproduction, ecology and genetics, as far as this was possible at that time. A conspicuous trait of Vandel is his fondness for small species as trichoniscids, and anybody who has tried to make preparations of the pleopods of a two-millimeter long Trichoniscus knows that you must have a very steady hand not to lose some important parts.

Vandel died in 1980, aged 86. An obituary was published by ANGeLIER (1982).

\section{Hans Strouhal}

The youngest of these four prominent isopodologists was Hans Strouhal (1897-1969) (Fig. 8). He was born in Vienna, where he first held positions at the university and after the World War II at the Natural History Museum, from 1951 to 1963 as director. He worked not only on isopods but published also on different insect groups. The first of his 66 papers on isopods appeared in 1927. He was a very accurate and systematic researcher, and his descriptions were always accompanied by high-quality illustrations. His main field of interest was Eastern Europe from Austria to Turkey, and a few publications deal with material from Africa and South America (Fig. 9)*.

An obituary was published by MAx BeIER (1969).

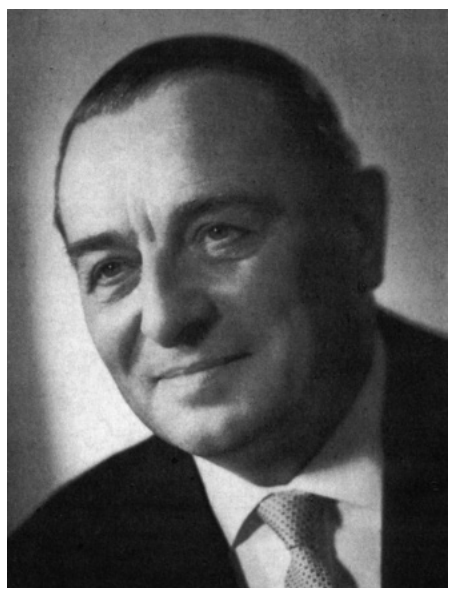

Fig. 8. Hans Strouhal (18971969), Austrian isopodologist (from Scholler 1962)

* Figures 9-42 are to be found only in the digital supplement of this paper. 
Additional researchers 1900-1945

Of course, these four prominent specialists were not the only scientists who worked on terrestrial isopods in the first half of the 20th century.

The following researchers also dealt with systematics and distribution of the Oniscidea:

- Harriet Richardson (USA, 1905 monograph on all isopods of North America and 20 publications on terrestrial isopods between 1899 and 1926); (Fig. 10);

- William van Name (USA, 1936 monograph on land and freshwater isopods of North and South America and 6 publications on terrestrial isopods between 1920 and 1942);

- $\quad$ Alessandro Brian (Italy, 40 publications mainly on Italian species); (Fig. 11)

- Walter Collinge (Great Britain, 20 articles, worldwide);

- Harold Gordon Jackson (Great Britain, 19 publications, worldwide);

- Zdenek Frankenberger (Czechoslovakia, 20 papers on the Balkans);

- Werner Herold (Germany, 26 publications mainly on central Europe, with one large paper on the Australasian islands);

- Charles Chilton (New Zealand, 21 papers mainly on Australian region);

- Keppel Harcourt Barnard (South Africa, 13 publications mainly on Africa).

The most important non-taxonomic publications between1900-1945 are by Аввот (1940), Авraham and Wolsky (1930), Allee (1926), Angelini (1935) Barnard (1924), Barnes (1940), Bateman (1933), Bazire (1945), Bertossi (1938), Bock (1942), Bruntz (1907), Chandy (1939), Geiser (1929), Jackson (1928), Kleinholz (1937), Mödlinger (1931), Müller (1925), Murlin (1902), Numanoi (1937), Nusbaum-Hilarowicz (1917), Okay (1945), O’Mahoney (1931), Poisson (1928), Racovitza (1925), Radu (1931), Reinders (1933), Sснwenck (1927), UNWIN (1932).

In this period an increasing number of publications on biological aspects other than taxonomy were published.

\section{RESEARCH ON TERRESTRIAL ISOPODS 1945 - TODAY}

Now we come to the period between the end of World War II and today, which was a time of constant economic development in the industrialized countries. Due to a growing interest in natural sciences and to increasing financial possibilities more and more scientists could be employed to investigate natural phenomena and processes. This situation was reflected even by the number of researchers working on such unspectacular and economically uninteresting organisms as terrestrial isopods. So in this period the number of publications on terrestrial isopods was multiplied, compared with former 
periods. On the one side, many new species were discovered, especially in the tropics, which was also due to the improved possibilities to travel to foreign countries (technically and politically). On the other hand, there was a great progress concerning the technical development (e. g., the scanning electron microscope). Due to this progress in techniques and methods completely new fields of research opened up, as for example genetics and molecular biology. So I can draw only a rough sketch of this development in the different biological fields.

We start again with systematics. Three of the four prominent researchers on systematics in the first half of the 20th century continued their work after World War II. The oldest, Verhoeff, had died in 1944, Arcangeli lived and worked until 1965, Strouhal until 1969, and Vandel until 1980.

\section{America}

In the following list of the post-war taxonomists, we go from west to east and start in America. And of course, I have to restrict myself to those authors with rather important contributions to isopod systematics.

George Schultz (Fig. 12) is the only recent specialist for terrestrial isopods in the USA. He started to publish on oniscideans in 1961 and made important contributions to the knowledge of terrestrial isopods of North and South America and Eastern Asia (more than 50 publications).

Enrique Rioja published 9 papers on the Oniscidea of Mexico between 1950 and 1964.

Alceu Lemos de Castro contributed with 25 publications to the knowledge of Brazilian woodlice (1952-1991).

In 1994 Paula de Araujo (Figs 13-14) began to publish on terrestrial isopods from the southern part of Brazil. In the meantime, she and a number of co-authors have released numerous articles on the systematics of the Oniscidea, and she still is very active in this field, together with her colleagues and students (e.g., Ivanklin Soares Campos-Filho) at the University of Porto Alegre.

\section{Great Britain}

In Great Britain, the taxonomic research was restricted to the native species in that post-war period. It is, however, the only country in which an Isopodological Society exists (the official name is British Myriapod and Isopod Group). They organize annual meetings with field excursions. This led to the production of a complete distribution atlas of around 30 native species of woodlice found in the country (Harding \& Sutton 1985). Stephen Sutton (Fig. 15) produced an identification key for some 40 British species. 
The Netherlands, Denmark, Norway

In the Netherlands, in Denmark and Norway national monographs on woodlice have been published (Holthuis 1956, Berg et al. 2008, Meinertz 1964, SARS already in 1899).

\section{France and Iberian Peninsula}

In France, Albert Vandel was still very active on an international scale until his death in 1980. In 1960 and 1962 he published an extremely detailed and comprehensive monograph on the woodlice of France in two volumes with more than 900 pages and illustrations for every one of the 166 species treated.

Further contributions to the systematics of mainly French woodlice are due to Jean-Jacques Legrand (44 publications on many biological aspects between 1942 and 1986) and Henry Dalens (more than 50 publications beginning in 1962).

In Spain, two young colleagues were active in the 1990ies. Antonio Cruz published on material from northern Spain (11 publications), and Rafael Rodriguez (Figs 16-17) made a Ph.D. thesis on the woodlice of the Canary Islands, with 8 subsequent publications.

In 1971 the Austrian Karl Schmölzer published a species list of the Iberian Peninsula.

\section{Germany and Switzerland}

In 1965-66 a detailed monograph of the Isopoda of Germany appeared in two volumes, written by Hans-Eckard Gruner. The second volume treated the 46 species of woodlice known at that time from Germany. This book contains high-quality illustrations of the diagnostic characters of every species and identification keys for every genus, and it is still the best guide for the identification of the species of Central Europe.

In 1972 a person called Helmut Schmalfuss appeared on the isopodological stage with some small articles on woodlice from Greece. This person is the author of the present paper, so that I will go a little bit more into details about my isopodological career. In 1973 I received some terrestrial isopods from Cameroon. Since I was young and eager, but inexperienced, I wrote to Franco Ferrara from Florence in Italy whether he would like to co-operate on these African animals.

He had started in 1971 to publish on terrestrial isopods from Africa, and immediately agreed that we work together on the African material. Finally this lead during the next ten years to the production of a revision of all terres- 
trial isopods from West Africa. Franco was the driving force, he went to many museums to investigate collections from western Africa. In the meantime, I had found a permanent position at the Natural History Museum of Stuttgart and thus could go on working and publishing on terrestrial isopods. I did this, mainly concerning systematics and distribution of woodlice in the eastern Mediterranean region, until I officially retired from the museum position ten years ago, but continued to work on isopods on a reduced scale until last year.

Around 1990 Friedhelm Erhard produced, under my supervision, a Ph.D. thesis on comparative anatomy of terrestrial isopods to clarify phylogenetical questions. After this, he published a number of further papers on anatomy and phylogeny of isopods (also including non-oniscideans) with very impressive complex three-dimensional illustrations. Unfortunately, he stopped with these investigations because he did not find an adequate position in a scientific institution.

In 1997 two young colleagues, Christian Schmidt and Andreas Leistikow, produced their first publications. They were followed by a number of extensive papers on woodlice from tropical America and other regions, with extremely good illustrations, but both of them again stopped working with isopods because they could not find any adequate positions.

In Switzerland, Jean Carl published already in 1908 a monograph on the terrestrial isopods of the country.

Italy

In Italy, Alceste Arcangeli was still active until 1963.

Domenico Caruso in Catania on Sicily started 1968 to publish on isopods with a number of colleagues and students. He and his team worked mainly on Sicily and northern Africa,

In Rome, Alberto Argano appeared on our stage in 1973, working mainly on Italian isopods.

Franco Ferrara (Fig. 18) also had found a permanent position in Florence in a research program on faunistics and ecology of the tropics, and after a couple of years he found a student whom he convinced to prepare a Ph.D.thesis on the woodlice of the Tuscan Archipelago. His name was Stefano Taiti, and in the following 25 years Franco and Stefano published dozens of extensive monographs on regional isopod faunas or comprehensive revisions of genera with thousands of incredibly detailed illustrations and descriptions of hundreds of new species from all over the world. Ten years ago Franco retired because of health problems, while Stefano remained world-wide the only fulltime specialist for the systematics of terrestrial isopods at a global scale, until he officially also retired in 2017. 


\section{Czechia}

Zdenek Frankenberger started already before World War II and produced 20 publications on the Oniscidea of the Balkans between 1937 and 1964, with two papers on material from western Asia.

Marie Flasarová (Fig. 19) also published 20 papers between 1958 and 2000 on the terrestrial isopods from her country.

\section{Austria}

Hans Strouhal was active until his death in 1969.

Karl Schmölzer (Fig. 20) produced 17 publications on Oniscidea from Europe and Africa between 1951 and 1974. In 1965 he published an identification key for all terrestrial isopod species of Europe. As it was to be expected for a key on hundreds of species extracted only from the literature without investigating the type material this construction contains many deficiencies.

\section{Hungary}

Already in 1926 Ernő Csiki had compiled a monograph on the terrestrial isopods of the Hungarian Empire of that time (including Dalmatia, Bosnia and Hercegovina), which contains 110 species. In 1942 Endre Dudich supplemented this list, and in 1998 L. Forró and S. Farkas published an updated checklist of the Oniscidea of Hungary. G. Ilosvay and I. Loksa have published on faunistics of terrestrial isopods in Hungary, in the first half of the 20th century some publications on taxonomy by L. Méhely and A. Kesselyák had appeared.

For a complete bibliography on Hungarian Oniscidea please consult ForRó and FARKAS (1998).

\section{Ex-Yugoslavia}

Adem Buturović, active 1954-1960, produced 9 publications on Ex-Yugoslavian Oniscidea.

Mladen Karaman, active 1961-1974, published a check-list of the terrestrial isopod species of Ex-Yugoslavia and a few additional articles on material from this country. His son Ivo Karaman continues the research on the isopod fauna of that region.

Milika Pljakić, active 1970-1977, contributed with 7 publications to the knowledge of Serbian Oniscidea. 
Romania and Bulgaria

Vasile Radu published between 1931 and 1979 some 40 papers on the Romanian isopod fauna. His publications are equipped with highly professional illustrations.

Ionel Tabacaru (Fig. 21) (first publication 1963) produced more than 20 contributions to the knowledge of Roumanian isopods, mainly Trichoniscidae.

Nicolae Tomescu (first publication 1972) produced more than a dozen publications on Roumanian Oniscidea.

Stoitze Andreev had his first publication in 1970 and contributed with some 15 papers to the knowledge of terrestrial isopods from Bulgaria and Greece.

\section{Greece}

Jannis Matsakis published between 1955 and 1979 mainly on Greek isopods.

Spyros Sfenthourakis started with a Ph.D. thesis on the terrestrial isopods of the Aegean islands. His first publication appeared in 1991, and since then he publishes continuously not only on systematics of Greek isopods, but also on phylogenetical questions and biogeographical theories.

\section{Russia}

Evgenii Borutzky (Fig. 22) worked mainly on Copepoda (first publication 1925) but produced additionally 34 publications between 1939 and 1978 (posthumous, he died in 1976) on terrestrial isopods from the Soviet Union.

Konstantin Gongalsky publishes on Oniscidea (mainly from the Caucasus region) since 2004.

Iran

Ghasem Kashani publishes on terrestrial isopods from Iran since 2010.

\section{South Korea}

Do Kwon contributes with publications since 1993 to the knowledge of terrestrial isopods from Eastern Asia.

Japan

Noboru Nunomura (Fig. 23) started to publish on isopods (also on marine groups) in 1979. In further publications he has described many new spe- 
cies, a considerable number of which have in the meantime been shown to be synonyms.

\section{Australia}

Alison Green was active from 1961 to 1990, in which time she produced 10 publications on Oniscidea from the Australian region.

\section{SYMPOSIA}

It is now time to mention the fact that from 1983 onwards international symposia on the biology of terrestrial isopods were held at rather regular intervals. It is generally agreed that these meetings are an excellent possibility for all zoologists working with terrestrial isopods to inform themselves about the state of knowledge in those scientific fields other than one's own specialty.

Symposia on the Biology of Terrestrial Isopods:

- $\quad$ 1. London 1983, organized by S. Sutton and D. Holdich;

- 2. Urbino (Italy) 1986, organized by R. Argano, P. del Grande, F. Ferrara, C. Manicastri, H. Schmalfuss and S. Taiti;

- $\quad$ 3. Poitiers (France) 1990, organized by P. Juchault and colleagues;

- 4. Haifa (Israel) 1997, organized by E. Hornung and M. Warburg;

- $\quad$ 5. Irakleio (Greece) 2001, organized by S. Sfenthourakis;

- 6. Aveiro (Portugal) 2004, organized by S. Loureiro and colleagues;

- 7. Tunis (Tunisia) 2007, organized by F. Charfi-Cheikhrouha and colleagues;

- $\quad$ 8. Bled (Slovenia) 2011, organized by J. Štrus and colleagues;

- 9. Poitiers (France) 2014, organized by D. Bouchon and colleagues;

- $\quad$ 10. Budapest (Hungary) 2017, organized by E. Hornung and colleagues.

\section{RESEARCH BEYOND TAXONOMY AFTER 1945}

We now come to the research beyond taxonomy. In these fields normally we have authors who are not specialized on terrestrial isopods, they investigate this group for comparisons with other animal groups. We make a short review through a number of different biological aspects, and I give a list of authors who have been active in these fields. These lists are certainly not complete, and the publication examples were randomly selected and do not mean any quality judgement.*

* If a number does not follow the author's name, check her/his publications at ScHmALfuss, H. \& Wolf-Schwenninger, K. (2002): A bibliography of terrestrial isopods (Crustacea: Isopoda: Oniscidea). - Stuttgarter Beiträge zur Naturkunde, Serie A 639: 1-120, or http:// www.oniscidea-catalog.naturkundemuseum-bw.de/ 
Distribution and biogeography

Most taxonomists have contributed to the knowledge of distribution, e. g., by presenting records in maps and trying to find explanations for different distribution types. There is only one paper using terrestrial isopods to test biogeographical theories (SFenthouraKis \& Giokas 1998), as far as I know (Fig. 24).

\section{External morphology}

Again many taxonomical publications contain information and illustrations on the external morphology of the Oniscidea. Functional interpretations you find in the publications of Caruso, Hoese (1982), Schmalfuss, etc. (Fig. 25).

\section{Anatomy}

Anatomical investigations were performed by Jackson, Flasarová, Alikhan, Storch, Štrus and colleagues, Erhard, Schmalfuss (e.g., see Erhard 1997, ŠTrus \& BLEJEC 2001) (Figs 26-27).

\section{Phylogeny (including molecular biology)}

Phylogenetic researches have been carried out by Schmalfuss, ERHARD (1998) (based on anatomy) (Fig. 28), Mattern, Michel-Salzat \& Bouchon, Sfenthourakis and colleagues (based on DNA analysis). Phylogenetic relationships inside the Oniscidea were investigated by ERHARD (1998).

\section{Cuticle, molt}

Results on cuticle research can be found in the publications of Holdich, Schmalfuss, Ziegler et al. (2006) etc. (Fig. 29).

\section{Ecology (including nutrition)}

Mark Hassall and his co-workers have, during the past 40 years, done some really enlightening experimental ecological investigations, e. g. on interspecific competition. In the publications of Araujo and colleagues, CAREFOOT (1973), Charfi-Cheikhrouha and colleagues, Fraj et al. (2008), Gere (1956), Hopkin (1990) (heavy metals), Hornung and Warburg (1995), ShachaK et al. (1979) (on Hemilepistus), Sutton, Szlávecz, Tajovsky, Tomescu, Vilisics, Warburg and Zimmer more ecological data and bibliographies of older publications can be found (Figs 30-37). 


\section{Behaviour}

Studies on behaviour have been performed by Cloudsley-Thompson, Linsenmair, Hoffmann, Sнаснак et al. (1979) (on Hemilepistus), Charfi-Cheikhrouha and colleagues (Figs 38-39).

\section{Nervous system and sense organs}

In this field research has been published by de Lattin, Fischbach, Kuers, Gupta, Alexander, Holdich, Haug \& Altner (1984), Schmalfuss, Zimmer, Niida, Molnar and others.

\section{Sex determination and reproduction}

Studies in this field have been undertaken by Vandel, Legrand and Juchault et al. (1993) in Poitiers, Katakura, Hasegawa et al. (1991), Warburg (1994), Hornung etc. (Figs 40-41).

\section{Physiology and biochemistry}

And finally quite a number of authors occupied themselves with detailed physiological and biochemical investigations: EDNEY $(1964,1968)$, Wieser, Lindquist (1968), Juchault, Mocquard and colleagues in Poitiers, HopKin (1990), Alikhan (1973), Warburg, Carefoot et al. (1991), Katakura. For the special field of ecotoxicology check the publications and bibliographies of Hopkin and Hornung.

You see that isopodology has developed in these last 70 years into a broad, manifold and complex biological science.

So even such a universal genius as Aristoteles would have been very fascinated by the all these aspects of the life of woodlice (Fig. 42).

Acknowledgements - Dr. Elisabeth Hornung (Budapest) suggested to prepare an overview of the history of research on terrestrial isopods as a presentation on the symposium in Budapest in August 2017. Dr. Gábor Bakonyi (Budapest) kindly helped to turn this presentation into a publishable manuscript. Dr. Spyros Sfenthourakis (Nicosia/Cyprus) informed me of Aristoteles' chapter on terrestrial isopods. Ulf Harr (Ulm/Germany) provided the cartoons of Aristoteles, which he had created with great enthusiasm. Two (officially) anonymous reviewers made a number of helpful suggestions and comments to improve the manuscript. To all of them, I wish to express my sincere thanks. 


\section{BIBLIOGRAPHY}

Аввот, С. (1940): Shore isopods: Niches occupied, and degrees of transition toward land life with special reference to the family Ligydidae. - Proceedings of the 6th Pacific Science Congress 3: 505-511.

Aвraham, A. \& Wolsky, A. (1930): Die Geruchsorgane der Landisopoden. - Zoologischer Anzeiger 84: 316-323.

Alikhan, M. (1973): Ionic content of the haemolymph in Porcellio laevis. - Comparative Biochemistry and Physiology 44A: 47-54.https://doi.org/10.1016/0300-9629(73)90368-X

Allee, W. (1926): Studies in animal aggregations: Causes and effects of bunching in land isopods. - Journal of Experimental Zoology 45(1): 255-277. https://doi.org/10.1002/ jez.1400450108

ANGELIER, E. (1982): Albert Vandel (1894 - 1980). Bulletin de la Société d'histoire naturelle de Toulouse 118: 21-23.

Angelini, G. (1935): Osservazioni sulla struttura del mesointestino di Armadillidium. Memorie della Società Toscana di Scienze naturali 45: 1-15.

Arcangeli (1935): Eoniscus simplicissimus, un pigmeo degli isopodi terrestri, appartenente a nuova specie, nuovo genere, nuova famiglia. - Bollettino di Zoologia 6: 203-212. https://doi.org/10.1080/11250003509435624

BACCI, G. (1967): Alceste Arcangeli (1880-1965). - Annuario della Universitá degli Studi di Torino 1965-66: 483-484 and 1 plate.

BARNARD, K. H. (1924): The digestive canal of isopod crustaceans. - Transactions of the Royal Society of South Africa 12: 21-36. https://doi.org/10.1080/00359192409519296

BARnes, T. (1940): Experiments on Ligia in Bermuda. VII. Further effects of sodium, ammonium and magnesium. - Biological Bulletin. Marine Biological Laboratory, Woods Hole 78: 35-41. https://doi.org/10.2307/1537798

Bateman, J. (1933): Osmotic anionic regulation in the shore crab, Carcinus maenas, with notes on the blood concentrations of Gammarus locusta and Ligia oceanica. - Journal of Experimental Biology 10: 355-371.

BAzire, G. (1945): Note préliminaire sur l'étude chimique et physiologique des pigments de quelques isopodes terrestres. - Bulletin Biologique de la France et de la Belgique 79: 67-74.

Beier, M. (1969): Hans Strouhal. - Annalen des Naturhistorischen Museums in Wien 78: 35-36.

Bertossi, F. (1938): Ricerche sulla pigmentazione di Androniscus Boldorii Strouhal in condizioni normali e sperimentali. - Bollettino di Zoologia 9: 125-129. https://doi. org/10.1080/11250003809436991

BовкETZKY, N. (1874): Zur Embryologie des Oniscus murarius. - Zeitschrift für wissenschaftliche Zoologie 14: 179-203.

Воск, A. (1942): Über das Lernvermögen der Asseln. - Zeitschrift für vergleichende Physiologie 29: 595-637. https://doi.org/10.1007/BF00304683

BRANDT, E. (1871): Ueber den Albinismus bei den Kellerasseln (Porcellio scaber). - Horae Societatis entomologicae rossicae 8: 167-176.

Bruntz, L. (1907): Sur l'existence d'organes globuligènes chez les isopodes. - Archives de Zoologie Expérimentale et Générale, 4e Série 7: 1-67, pls 1-5.

Carefoot, T. (1973): Feeding, food preference, and the uptake of food energy by the supralittoral isopod Ligia pallasii. - Marine Biology 18: 228-236. https://doi.org/10.1007/ BF00367989 
Carefoot, T., Mann, M. \& Kalwa, S. (1991): The effect of desiccation on oxygen uptake in terrestrial isopods. Pp. 157-164. In: Juchault, P. \& Mocquard, J. (eds): Biology of Terrestrial Isopods, Third International Symposium, Poitiers.

Chandy, M. (1939): The histology and physiology of the intestine and hepatopancreas of two isopods, Ligia exotica and Armadillo elevatus. - Journal of the Asiatic Society of Bengal 4: 1-16.

Conklin, E. (1897): The relation of nuclei and cytoplasm in the internal cells of the land isopods. - American Naturalist 31: 66-71.

Duvernoy, G. \& Lereboullet, A. (1841): Essai d'une monographie des organes de la respiration de l'ordre crustacés isopodes. - Annales des Sciences naturelles, Série 1 15: 177-240, pl. 6.

EDNEY, E. (1964): Acclimation to temperature in terrestrial isopods. II. Heart rate and standard metabolic rate. - Physiological Zoology 37: 378-394. https://doi.org/10.1086/physzool.37.4.30152756

EdNeY, E. (1968): Transition from water to land in isopod crustaceans. - American Zoologist 8: 309-326. https://doi.org/10.1093/icb/8.3.309

ERHARD, F. (1997): The pleonal skeleton and musculature of Titanethes albus and of further taxa of the Oniscidea, with conclusions on the phylogeny of terrestrial isopods. Stuttgarter Beiträge zur Naturkunde, Serie A 550: 1-70.

ERHARD, F. (1998): Phylogenetic relationships within the Oniscidea. - Israel Journal of Zoology 44: 303-309.

Forró, L. \& FARKAS, S. (1998): Checklist, preliminary distribution maps, and bibliography of woodlice in Hungary (Isopoda: Oniscidea). - Miscellanea zoologica hungarica 12: 21-44.

Fraj, M., El Gtari, M. \& Charfi-Cheikhrouha, F. (2008): Density and distribution of burrows of the desert isopod Porcellio albinus in two habitats of the Kebili region (Tunisia). Pp. 113-116. In: Zimmer, M., Charfi-Cheikhrouha, F. \& Taiti, S. (eds): Proceedings of the International Symposium of Terrestrial Isopod Biology, ISTIB-07.

Friedrich, H. (1883): Die Geschlechtsverhältnisse der Onisciden. - Zeitschrift für die gesammten Naturwissenschaften (Halle) 56: 447-474, Plate 5.

Geiser, S. (1929): Albinism in terrestrial Isopoda. - Anatomical Record 44: 246-247.

Gere, G. (1956): The examination of the feeding biology and the humificative function of Diplopoda and Isopoda. - Acta Biologica Academiae Scientiarum Hungaricae 6: 257-271.

Harding, P.T., Sutton, S.L. (1985): Woodlice in Britain and Ireland: Distribution and habitat. Institute of Terrestrial Ecology, Huntingdon, pp. 151.

Hasegawa, Y, Katakura, Y. \& Haino-Fukushima, K. (1991): Immunological study on androgenic gland hormone Armadillidium vulgare. Pp. 177-181. In: Juchault, P. \& MoceuARD, J. (eds): Biology of Terrestrial Isopods, Third International Symposium, Poitiers.

Hassall, M. \& Dangerfield, M. (1989): Inter-specific competition and the relative abundance of grassland isopods. - Monitore zoologico italiano (N. S.), Monographs 4: 379-397.

Haug, T., \& Altner, H. (1984): A cryofixation study of presumptive hygroreceptors on the antennule of a terrestrial isopod. - Tissue and Cell 16(3): 377-391.

Hoese, B. (1982): The Ligia-type of the water conducting system in terrestrial isopods and its development in the family Ligiidae. - Zoologische Jahrbücher für Anatomie 108: 225-261.

HоркIN, S. (1990): Critical concentrations, pathways of detoxification and cellular ecotoxicology of metals in terrestrial arthropods. - Functional Ecology 4: 321-327. https://doi. org/10.2307/2389593 
Hornung, E. \& WARburg, M. (1995): Seasonal changes in the distribution and abundance of isopod species in different habitats within the Mediterranean region of northern Israel. - Acta CEcologica 16: 431-445.

Huet, L. (1883): Nouvelles recherches sur les crustacés isopodes. - Journal de l'Anatomie et de la Physiologie normales et pathologiques de l'Homme et des Animaux 19: 241-376, Plates $12-15$.

Jackson, H. (1928): The morphology of the isopod head. Part II. The terrestrial isopods. - Proceedings of the Zoological Society of London 1928: 561-595. https://doi. org/10.1111/j.1469-7998.1928.tb07159.x

Jeppesen, P. (2000): Catalogue of terrestrial isopod taxa and type material described by Gustav Budde-Lund (Crustacea: Isopoda). - Steenstrupia 25: 221-265.

Juchault, P., Rigaud, T. \& Mocquard, J. (1993): Evolution of sex determination and sex ratio variability in wild populations of Armadillidium vulgare: a case study in conflict resolution. - Acta CEcologica 1993: 547-562.

Kleinholz, L. (1937): Studies in the pigmentary system of Crustacea. I. Color change and diurnal rhythm in Ligia baudiniana. - Biological Bulletin. Marine Biological Laboratory, Woods Hole 7: 24-36. https://doi.org/10.2307/1537536

Leydig, F. (1878): Ueber Amphipoden und Isopoden. Anatomische und zoologische Bemerkungen. - Zeitschrift für wissenschaftliche Zoologie 30(Suppl.): 225-274.

Lindeuist, O. (1968): Water regulation in terrestrial isopods, with comments on their behavior in a stimulus gradient. - Annales zoologici fennici 5: 279-311.

Linsenmair, K.-E. (1979): On the sociobiology of the desert isopod Hemilepistus reaumuri and related species: pairbond and evolution of monogamy. - Verhandlungen der Deutschen Zoologischen Gesellschaft 1979: 60-72.

Lopes, E., Mendonça, M., Bond-Buckup, G. \& Araujo, P. (2005): Oniscidea diversity across three environments in an altitudinal gradient in northeastern Rio Grande do Sul, Brazil. - European Journal of Soil Biology 41: 99-107. https://doi.org/10.1016/j.ejsobi.2005.11.002

Martynov, N. (1896): [Biological studies on woodlice.] - Mémoires de l'Académie impériale des Sciences de St.-Pétersbourg, Série 8 3: 1-14, Plate 1. [in Russian]

McMurrich, J. (1895): Embryology of the isopod Crustacea. - Journal of Morphology 11: 63-154. https://doi.org/10.1002/jmor.1050110103

McMurrich, J. (1898): The epithelium of the so-called midgut of the terrestrial isopods. Journal of Morphology 14: 83-108.

Mocquard, J. (1979): Écophysiologie de la reproduction des isopodes terrestres. - Bulletin de la Société des Sciences naturelles de Tunisie 14: 59-72.

MöDlinger, G. (1931): Beiträge zur Morphologie der Respirationsorgane der Landisopoden. - Studia zoologica (Budapest) 2: 25-79.

MülLER, A. (1925): Über Lichtreaktionen von Landasseln. - Zeitschrift für vergleichende Physiologie 3: 113-144. https://doi.org/10.1007/BF00340861

Murlin, J. (1902): Absorption and secretion in the digestive system of land isopods. - Proceedings of the Academy of Natural Sciences of Philadelphia 54: 284-359.

Numanoi, H. (1937): Migration of calcium through blood in Ligia exotica during its moulting. - Japanese Journal of Zoology 7: 241-249.

Nusbaum, J. (1893): Materyaly do embryogenii i hisogenii rownonogow (Isopoda). - Abhandlungen der Krakauer Akademie der Wissenschaften, mathematisch-naturwissenschaftliche Klasse 25: 165-263.

Nusbaum, J. (1896): L'embryologie d'Oniscus murarius. - Zoologischer Anzeiger 9: 454-458. 
Nusbaum-Hilarowicz, J. (1917): Studien über die Physiologie der Verdauung bei den Landasseln (Isopoda). - Biologisches Zentralblatt 37: 49-55.

Окау, S. (1945): L'hormone de contraction des cellules pigmentaires chez les isopodes. Istanbul Üniversitesi Fen Fakültesi Mecmuasi, Serı B 10: 116-132.

O'Mahoney, E. (1931): A dipterous parasite of woodlice. - Entomologist's Monthly Magazine 67: 182.

Poisson, R. (1928): Eccrinopsis mercieri n. sp., eccrinide parasite du rectum de l'Oniscus asellus. Son cycle évolutif. - Comptes rendus hebdomadaire des Séances de l'Académie des Sciences (Paris) 186: 1765-1767.

RacovitZA, E. (1925): Notes sur les isopodes. 13. Morphologie et phylogénèse des antennes II. A. Le. - Archives de Zoologie Expérimentale et Générale 63: 533-622.

RAdu, V. G. (1931): Spermatogeneza la Armadillidium vulgare, cu privire-speciala asupra evolutiei chromatinei si a constituantilor cytoplasmatici. - Analele Academiei Române, Memoriile Secţiunii ştiinţifice (3) 8: 1-112.

Reinders, D. (1933): Die Funktion der corpora alba bei Pocellio scaber. - Journal of Comparative Physiology A: Neuroethology, Sensory, Neural, and Behavioral Physiology 20(1): 291-298.

Reinhard, W. (1887): Zur Ontogenie des Porcellio scaber. - Zeitschrift für vergleichende Physiologie 20: 291-298.

Roule, L. (1891): Sur le développement des feuillet blastodermiques chez les crustacés isopodes (Porcellio scaber). - Comptes rendus hebdomadaire des Séances de l'Académie des Sciences (Paris) 112: 1460-1462.

SchedL, W. (2005): In memoriam Dr. phil. Karl Schmölzer (1925-2004). - Berichte des naturwissenschaftlich-medizinischen Vereins in Innsbruck 92: 391-396.

Schmalfuss, H. (2003): World catalog of terrestrial isopods (Isopoda: Oniscidea). - Stuttgarter Beiträge zur Naturkunde, Serie A 654: 1-341. An updated version of this publication till 2004 can be found at http://www.oniscidea-catalog.naturkundemuseum-bw.de/

Schmalfuss, H. \& Wolf-Schwenninger, K. (2002): A bibliography of terrestrial isopods (Crustacea: Isopoda: Oniscidea). - Stuttgarter Beiträge zur Naturkunde, Serie A 639: 1-120. An updated version of this publication till 2004 can be found at http://www. oniscidea-catalog.naturkundemuseum-bw.de/

SснӧвL, J. (1880): Die Fortpflanzung isopoder Crustaceen. - Archiv für mikroskopische Anatomie 17: 125-140. https://doi.org/10.1007/BF02952569

Scholler, H. (1962): Hans Strouhal. - Annalen des Naturhistorischen Museums in Wien 65: VII-VIII.

SснӧNichen, W. (1899): Der Darmkanal der Onisciden und Aselliden. - Zeitschrift für wissenschaftliche Zoologie 65: 143-178.

Schwenck, J. (1927): Sobre un nematoide parasita de Oniscidae. - Boletim de Zoologia e Biologia Marinha (São Paulo) 10: 78-85.

Sfenthourakis, S. \& Giokas, S. (1998): A biogeographical analysis of Greek Oniscidean endemism. - Israel Journal of Zoology 44: 273-282.

Shachak, M., Steinberger, Y. \& OrR, Y. (1979): Phenology, activity and regulation of radiation load in the desert isopod, Hemilepistus reaumuri. - Oecologia 40: 133-140. https://doi.org/10.1007/BF00347931

Stoller, J. (1899): On the organs of respiration of the Oniscidae. - Zoologica (Stuttgart) 25: 1-31, Plates 1-2. https://doi.org/10.5962/bhl.title.119690

Strasser, K. (1949): In memoriam Dr. phil. Karl W. Verhoeff. - Naturwissenschaftliche Rundschau 2: 41-42. 
Štrus, J. \& BlejeC, A. (2001): Microscopic anatomy of the integument and digestive system during the molt cycle on Ligia italica. - Crustacean Issues 13: 343-352.

Sunderland, K. \& SutTon, S. (1980): A serological study of arthropod predation on woodlice in a dune grassland ecosystem. - Journal of Animal Ecology 49: 987-1004. https:// doi.org/10.2307/4240

UNwin, E. (1932): On the structure of the respiratory organs of the terrestrial Isopoda. - Papers and Proceedings of the Royal Society of Tasmania 1931: 37-104.

WAGNER, N. (1865): Recherches sur le système circulatoire et les organes de la respiration ches le porcellion élargi (Porcellio dilatatus). - Annales des Sciences Naturelles, Série 1 4 [no page numbers found]

WARBURG, M. (1994): Review of recent studies on reproduction in terrestrial isopods. - Invertebrate Reproduction and Development 26: 45-62. https://doi.org/10.1080/07924259.1 994.9672400

Weber, M. (1881): Anatomisches über Trichonisciden. - Archiv für mikroskopische Anatomie 19: 579-648. https://doi.org/10.1007/BF02952709

Uljanin, V. N. (1875): Crustacea. Isopoda. Pp. 4-21 and plates I-V. In: Fedchenko, A. P.: Journeys in Turkestan. Vol. 2: Zoogeographical researches. - Imperial Society of Naturalists, St. Petersburgh and Moscow. [in Russian, with descriptions in Latin]

Ziegler, A., Hagedorn, M., Ahearn, G. \& Carefoot, T. (2007): Calcium translocations during the moulting cycle of the semiterrestrial isopod Ligia hawaiiensis. - Journal of Comparative Physiology B 177(1): 99-108. https://doi.org/10.1007/s00360-006-0112-9

Received December 6, 2017, accepted March 20, 2018, published August 1, 2018 


\title{
A Magyar Természettudományi Múzeum gyászbogártípusainak (Tenebrionidae) katalógusa \\ Type catalogue of darkling beetles (Tenebrionidae) preserved in the Hungarian Natural History Museum
}

\author{
by Ottó Mer KL, Aranka Grabant \& Zoltán SoltésZ
}

The Hungarian Natural History Museum (HNHM) houses one of the largest and most complete Tenebrionidae collections of the world, thanks to Zoltán Kaszab (1915-1986), the Museum's former General Director and the most prominent figure of Hungarian coleopterology. The book is a commemoration of the centenary of his birthday.

The introduction summarises the history of the Hungarian Natural History Museum, its Coleoptera Collection and the scientific activity of Zoltán Kaszab.

Type specimens constitute the scientifically most valuable assets of the collection. The catalogue contains types of all the species, subspecies, variations and aberrations which have ever been described in the family Tenebrioni-

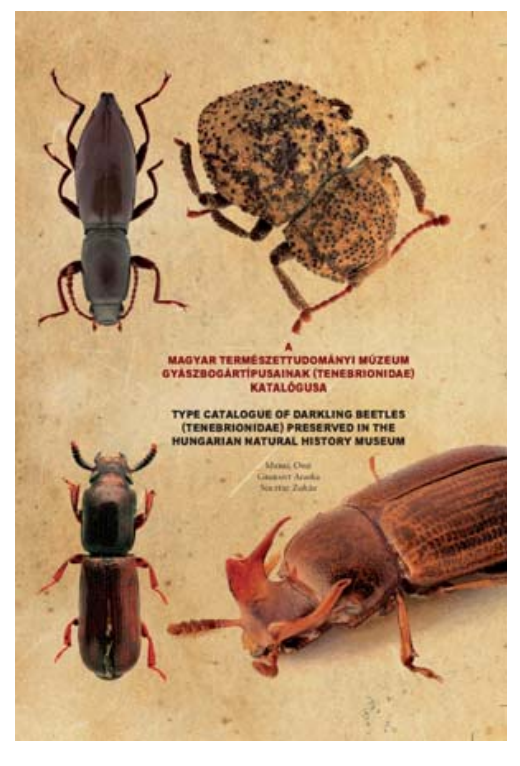
dae, and kept in the HNHM, including those already assigned to other families, as well as those which were described in different families but are now members of Tenebrionidae. A total of 21,313 type specimens belonging to 5,941 names are listed herein, including 1,222 holotypes, 4 neotypes, 88 lectotypes, 4,914 syntypes, 86 allotypes, 248 paralectotypes and 14,751 paratypes. The list of the names is followed by a complete list of the 1,212 publications containing the original descriptions.

Merkl, O., Grabant A. \& Soltész Z. (2015): A Magyar Természettudományi Múzeum gyászbogártípusainak (Tenebrionidae) katalógusa. Type catalogue of darkling beetles (Tenebrionidae) preserved in the Hungarian Natural History Museum. - Hungarian Natural History Museum, Budapest, 735 pp.

ISBN 9789639877238 [hardcover]

Orders should be sent to:

The Library, Hungarian Natural History Museum

H-1083 Budapest, Ludovika tér 2, Hungary

Fax: (36-1) 3172320, e-mail: angela@nhmus.hu

Price: 9990 HUF, 30 EUR 